\title{
Dramatik a jeho soubor: dvě a půl sondy do české amatérské dramatiky po roce 2000 s pokusem o zobecňující úvod
}

\author{
Playwright and His Group: Two Insights Into Czech \\ Non-professional Drama After 2000 and a Half \\ (Plus an Attempt at a General Introduction)
}

Jan Šotkovský

\begin{abstract}
Abstrakt
Př́tomná studie se věnuje dílu tři výrazných amatérských dramatiků, jejich tvorbě po roce 2000 a jejich domovským souborům. Jde o Kazimíra Lupince (občanským jménem Jana Červeného) a soubor V.A.D. Kladno, Petra Macháčka a pražské Divadlo Kámen a Josefa Tejkla a soubor Černí šviháci z Kostelce nad Orlicí. V př́padě Lupince a Macháčka studie nabízí pokus o celistvé postižení jejich autorského typu, v Tejklově případě spíše zkoumá specifika, výhody a omezení ve vztahu amatérského dramatika a souboru, s nímž stabilně spolupracuje. Na toto téma studie předkládá také několik zobecňujících úvah. "Případovým studiím”, věnovaným jednotlivým autorům, předchází obsáhlý úvod, který líčí obecnější kontexty české amatérské dramatiky po roce 2000 a jistou paradoxnost její odborné a kritické recepce.
\end{abstract}

\section{Klíčová slova}

Amatérské divadlo; současné drama; Jiráskův Hronov; Kazimír Lupinec; Petr Macháček; Josef Tejkl

\begin{abstract}
The present paper deals with work of three outstanding non-professional playwrights active after 2000, and their home theatre groups: Kazimír Lupinec (real name Jan Červený) and his group V.A.D. Kladno; Petr Macháček and Divadlo Kámen, Prague; and Josef Tejkl and Černí šviháci, Kostelec nad Orlicí. The aim of the study, in case of Lupinec and Macháček, was to cover all aspects of their theatre work, while in case of Josef Tejkl the stress is laid on the dynamic relationship between the author and his group, and the advantages and disadvantages of their tight collaboration. Some general observations on this issue are made towards the end of the paper, while at the start an overall introduction to the context of Czech nonprofessional theatre after 2000 is given, stressing the somewhat paradoxical nature of its theoretical and critical reflection.
\end{abstract}

\section{Keywords}

Non-professional theatre; contemporary drama; Jiráskův Hronov Festival; Kazimír Lupinec; Petr Macháček; Josef Tejkl 


\section{Varování hned na začátek}

Přítomná studie vznikla z ambice důsledněji reflektovat tvorbu dvou pozoruhodných amatérských divadelníků - Kazimíra Lupince a Petra Macháčka. Doposud malá odborná pozornost věnovaná soudobému amatérskému divadlu si vynutila úvod, který črtá kolem zmíněných tvůrců obecnější kontexty a který nakynul více, než je jeho autorovi milé. Neměl by být ovšem vnímán jako pokus o komplexní charakterizaci české amatérské dramatiky po roce 2000: něco takového by vyžadovalo výzkum mnohem důslednější.

\section{Dvojlomné postavení amatérského divadla}

Kritická a odborná pozornost, která je v České republice věnovaná amatérské činoherní dramatice, má do jisté míry paradoxní rysy. Na straně jedné se může jevit jako poměrně výrazná - porotci, vesměs se rekrutující z řad divadelních a kritických profesionálů, rozebírají špičkové produkty amatérské dramatiky důkladně na regionálních i celostátních přehlídkách, v bulletinech dotyčných přehlídek ${ }^{1}$ vycházejí analyticky orientované recenze, obdobné texty uveřejňuje i specializovaný časopis Amatérská scéna, který v letech 2000-2007 vydával v rámci své Repertoárové přílohy texty amatérských autorů „prověřené jevištěm“, ${ }^{2}$ které byly většinou doplňovány obsáhlejším komentářem, tzv. dramaturgickým pendantem³. V porovnání se standardní úrovni české recenzentské praxe lze konstatovat, že kvalita reflexe, které se dostává české amatérské dramatice, je nezřídka vyšší, než je tomu u dramatiky profesionální.

Na straně druhé je amatérská dramatika stále vnímána jako oblast od dramatiky profesionální ostře oddělená, čehož důkazem je takřka naprostá absence zmínek o ní ve všech syntetičtějších publikacích o českém porevolučním dramatu - míním tím obsáhlé kolektivní monografie o literatuře po roce 1989 V souřadnicích volnosti (Academia 2008) a V souřadnicích mnohosti (Academia 2014), Přiběhy obyčejných šilenstvi (Akropolis 2015) Lenky Jungmannové ${ }^{4}$ a spíše esejisticky laděnou Krajinu s akvabelami a černým domem (Pulchra 2013) Jana Kerbra.

Jediný amatérský dramatik, který „pronikl“ do těchto publikací, je René Levínský, jehož ovšem vzhledem k četnosti uvádění jeho textů profesionálními divadly lze vnímat jako hraniční zjev, stojící na pomezí mezi amatérským a profesionálním divadlem. Pozornost je ovšem věnována pouze těm jeho textům, které byly hrány „i profesionály“,

$1 \quad$ Na základě víceleté zkušenosti si troufám tvrdit, že bulletiny českých celostátních amatérských přehlídek - se Zpravodajem Jiráskova Hronova v čele - kvalitou znatelně převyšují bulletiny renomovaných českých profesionálních festivalů.

2 Celkem v ní vyšlo v dané době 51 dramatických textů, mezi nimi i hry Petra Macháčka (Mlejnek, Marmeláda) a Kazimíra Lupince (Rozpaky zubaře Svatopluka Nováka, Hotel Infercontinental), kterými se budu v této studii podrobněji zabývat.

3 Jejich autory byli nejčastěji Jan Císař a Vladimír Zajíc.

4 V minulém čísle Theatralii knihu recenzovala Iva Mikulová (MIKULOVÁ 2017). 
Jungmannová ve své knize Přrběhy obyčejných šilenství i ve své kapitole v publikaci $V$ souřadnicích mnohosti detailněji pojednává o jediné jeho hře, kterou je Ještě žiju s věšákem, čepici a plácačkou, té je pak ve zmíněné publikaci věnována samostatná studie Zdeňka Hořínka (FIALOVÁ 2014: 637-643). Jedinou hrou vzniklou pro amatérský soubor, které se v knize $V$ souřadnicích mnohosti dostalo výraznější pozornosti, je tak Doma Martina Františáka, ${ }^{5}$ který ovšem jako autor „náleží amatérskému divadlu jen výraznou menšinou své tvorby (více o tom později).

V podkapitole „Publikační kontext“ kapitoly knihy $V$ souřadnicích mnohosti věnované dramatu (FIALOVÁ 2014: 610-613), která jinak pojednává vydávání současné české dramatiky vskutku vyčerpávajícím způsobem, není o zmíněné publikační činnosti Amatérské scény, relevantní minimálně rozsahem a soustavností, jediná zmínka.

Tato dvojlomnost ovšem odráží obecnější rozměr problematiky postavení amatérského divadla v české divadelní kultuře. Amatérské divadlo tvoří přirozenou zásobárnu talentů pro budoucí studium na divadelních školách, řada profesionálních divadelníků z něj tudíž tak či onak „vzešla“ a cítí chut či potřebu mu to nějakým zpơsobem „vracet“ - at formou spolupráce s konkrétním souborem, porotní činností či vedením rozličných seminářů a workshopů (jen z režisérů - Milan Schejbal, Aleš Bergman, Petr Hašek, Martin Vokoun, Štěpán Pácl...). Konkrétní vazby profesionálů s amatérským divadelním prostředím jsou četné a mají nejrůznější motivace, počínaje možností splnit si „u ochotníků“ divadelní sny, jejichž realizaci dotyčnému profesionální divadlo neumožňuje, a konče okouzlením prostředím, v němž je přirozená chut vést o viděném dialog mezi diváky i tvůrci výrazně větší než v divadle profesionálním. Přesto existuje mezi profesionálními tvưrci i tzv. odbornou veřejností řada intenzivních předsudků vůči amatérskému divadlu (vesměs, jak lze očekávat, tím intenzivnějších, oč méně se opírají o přímou diváckou zkušenost), která znemožňuje pojednávat i vrcholné inscenace amatérského divadla bez jejich apriorního umístění na nižší hodnotový stupeň. ${ }^{6} \mathrm{Na}$ druhou stranu je evidentní, že od roku 2000 se na oné nepropustnosti mentální bariéry mezi profesionály a amatéry mnohé změnilo. Máme zde vzorový příklad pozvolného, řadu let trvajícího „přesunu“ výrazného amatérského tvưrce do pozice respektovaného profesionálního režiséra v osobě Jiř́iho Jelínka; existují divadelní festivaly, které vedle sebe dokáží stavět profesionální a amatérské inscenace jako rovný s rovnými (...př́̌ští vlna/next wave..., Přelet nad loutkářským hnízdem7); existují pozoruhodné nezávislé soubory, které se profesionalizovaly dlouhá léta a velmi pozvolně, jakoby s neochotou

5 Opět ve studii Zdeňka Hořínka (FIALOVÁ 2014: 707-712).

6 Připouštím, že zmíněné tvrzení zní poněkud svévolně a nedoloženě, nedokáži jej opř́í o nic jiného než o vlastní anecdotal evidence, přesto jsem se s dotyčnými předsudky setkal tolikrát a jsem o jejich skrytém vlivu natolik přesvědčen, že je zde nemohu nezmínit.

7 Loutkářská komunita se v tomto ohledu od činoherní značně odlišuje, pocit soudržnosti v rámci menšinového druhu divadla zde často dominuje nad členěním na amatéry a profesionály. Příkladem není jen bilanční Přelet nad loutkářským hnízdem, ale i poslední ročníky Loutkářské Chrudimi se stále se rozšiřujícím doprovodným programem složeným z „inspirativních“ profesionálních představení - tento program přitom nijak nevzbuzuje stížnosti, že pozvané profesionální produkce nasazují amatérským loutkářům neadekvátní latku, které by velmi pravděpodobně na jiných amatérských přehlídkách nastaly. 
se zříkaly účinkování na amatérských festivalech"; rozšiřuje se „šedá zóna“ souborů „fringe“ typu, v jejichž řadách působí částeční či vyslovení profesionálové, kterým ale poskytuje svět amatérského divadla leccos cenného (od příležitostí k hraní přes divácké zázemí až ke kvalifikované zpětné vazbě).

Právě rozšiřování této „zóny překryvu“ stále více problematizuje otázku, koho lze při práci v amatérském divadle vlastně vnímat jako profesionála, kudy vést pomyslnou hranici (je určujícím kritériem fakt, že se dotyčný divadlem živí? Že vystudoval některou ze středních či vysokých divadelních škol?). Je to téma, které by si zasloužilo zřejmě samostatnou úvahu - autor textu se s ním často musel konfrontovat při udělování ocenění na amatérských přehlídkách. Letitá nepsaná zásada, která praví, že profesionál podílející se na amatérské produkci nemůže být oceněn, se stává v praxi stále hůře aplikovatelnou. Je kupř́íkladu televizní dramaturg režírující v amatérském divadle „profesionálem“ (příklad Lud'ka Horkého z pražského souboru Hrobeso)? Lze vnímat soubor složený z velké části z teatrologických a kritických profesionálů (pražský Antonín Puchmajer D.S.) jako v pravém slova smyslu amatérský? Kam zařadit absolventy vysokých škol, kteří provozují divadelní aktivitu pouze na amatérském poli (at̉ se už na tom profesionálním neuplatnili nebo o to ani neusilovali - zde je př́íkladů celá řada)?

Tento problém vede samožrejmě k otázce obecnější - k vymezení hranice mezi amatérským a profesionálním divadlem vůbec. Tvrdit, že „celý problém tohoto oddělování je přece dán prostým faktem ekonomickým“, jak zněl jeden z kritických komentářu k pracovní verzi této studie, mi připadá jako značné zjednodušení: 1) také či onaké vstupné vybírá naprostá většina amatérských souborů, 2) pro řadu amatérských divadelníků představuje divadelní činnost nikoli nevýznamný přivýdělek, aniž by se kvůli ní zřekli „občanského“ povolání a aniž by především kvůli tomu odmítali účast svých inscenací v amatérských soutěžích (které mohou zároveň být velmi funkčním marketingovým nástrojem v propagaci inscenace), 3) tvrdit, že každý amatér se stává profesionálem ve chvíli, kdy za svůj výkon přijímá honorář, je podobně málo metodologicky funkční jako tvrzení opačné, tj. že profesionál hrající zadarmo se stává amatérem. ${ }^{9}$

Pro účely naší studie tudíž zvolme poněkud pragmatické, ale - domnívám se - funkční kritérium, kdy za amatérský soubor považujeme takový, který bud’ operuje jen ve velmi omezeném komunikačním okruhu, daném primárně geograficky (zde by bylo asi přesnější mluvit o sousedském či ochotnickém divadle), anebo ten, který se k „amatérskosti“ sám aktivně přihlašuje účastí v systému soutěžních přehlídek. Pojem amatérská dramatika tudíž chápu jako množinu textů vznikajících primárně pro soubory, které operují ve zmíněných komunikačních okruzích amatérského divadla.

8 To platí třeba o souboru VOSTO5, a především o Geisslers Hofcomoedianten.

9 O tomto problému mohu psát z vlastní důvěrné zkušenosti více než desítiletého působení v divadle BURANTEATR, kde se po většinu existence souboru prakticky žádné herecké honoráře nevyplácely - nepovažovali jsme se kvůli tomu za amatérský soubor a nebralo nás tak ani okolí. 


\section{Dramatik a jeho soubor}

„Případové studie“, tvořící druhou část tohoto textu, se věnují dvojici dramatiků - Kazimíru Lupincovi (1976, občanským povoláním architekt) ${ }^{10}$ a Petru Macháčkovi (1968, občanským povoláním překladatel). Studie třetí, která se zaměřuje na tvorbu Josefa Tejkla (1952-2009, občanským povoláním pedagog ZUŠ), zkoumá pak spíše vzájemné ovlivňování dramatika a souboru, než že by usilovala o komplexní postižení jeho dramatické tvorby.

Ve všech třech případech jde o autory, kteří svou dramatickou tvorbou ovlivnili podobu českého amatérského divadla po roce 2000 nejvýrazněji. Hranici roku 2000 používám z několika důvodů - jednak zhruba vyznačuje vstup Kazimíra Lupince a Petra Macháčka do amatérského divadelnictví, jednak právě v tomto roce začíná zmiňované pravidelné vydávání textů amatérských dramatiků v Amatérské scéně. V období 19902000 se po mém soudu srovnatelně výrazní dramatičtí tvưrci na amatérské scéně neobjevili (za částečnou výjimku můžeme považovat tvorbu René Levínského). ${ }^{11}$

Právě René Levínský se ovšem při tomto výběru ocitl záměrně mimo oblast mého zájmu. Coby dramatik totiž výrazně propojuje světy divadla amatérského a profesionálního, a to hned na několik způsobů - píše texty pro domovský amatérský soubor Nejhodnější medvídci i pro rozličné profesionální scény, ${ }^{12}$ jeho texty psané pro amatéry jsou posléze uváděny u profesionálư ${ }^{13}$ i naopak. ${ }^{14}$

Pomíjím i druhého autora, který rovněž zásadním způsobem překlenuje onu pomyslnou mentální propast mezi amatérským a profesionálním divadlem, byt jaksi „z druhé strany“, Martina Františáka. Tento profesionální režisér je strůjcem zřejmě největšího porevolučního přijetí amatérské dramatiky ze strany profesionálního divadelnictví jeho hra Doma, napsaná pro DS Jana Honsy Karolinka, se pouhé dva roky po premiéře v Karolince (2005, režie autor) dočkala uvedení v pražském Národním divadle (2007, v jednom večeru s Jiráskovým Otcem pod společným názvem Otec/Doma, režie Michal Dočekal). Už samotná karolinská inscenace ovšem představuje od svého triumfálního přijetí na Jiráskově Hronově 2005 jakýsi obecně akceptovaný vrchol českého amatérského divadelnictví po roce 2000. Její recepce zásadně přesáhla mantinely amatérského divadla: „Soubor z Karolinky vrátil divadlu jeho naléhavost, působivost a pravdivost. Pro mě je jejich Doma nejen vrcholný zážitek letošního Hronova, ale celé uplynulé divadelní sezóny, ne-li posledních let.“ (HRDINOVÁ 2005) Inscenace se umístila na šestém

10 Občanské jméno Kazimíra Lupince je Jan Červený - v práci budu nadále používat pouze jeho umělecký pseudonym.

11 Ostatně i v př́ípadě zmíněného Josefa Tejkla, dramaticky tvořícího od konce 80 . let, lze říci, že jeho hry dochází největšího ohlasu až po roce 2000.

12 A to včetně pražského Národního divadla, kde byla loni poprvé uvedena jeho hra Dotkni se vesmíru a pokračuj (režie Jan Frič).

13 Jde zejména o Levínského vrcholný text Ještě žiju s věšákem, čepici a plácačkou, který se po prvním uvedení Nejhodnějšími medvídky (2001, režie Andrej Krob) dočkal hned čtyř profesionálních uvedení.

14 Hru Planoucí srdce, psanou pod pseudonymem Leo Egerstein pro Západočeské divadlo v Chebu, která tam byla uvedena s názvem Nawratilowa, Szymczykowa (2009, režie Zdeněk Bartoš), uvedli o rok později Nejhodnější medvídci již pod autorovým vlastním jménem s názvem Doubkowa hole má (režie Daniel Vavřík). 
místě v anketě Inscenace roku Divadelnich novin, byla natočena Českou televizí (2007, režie Janusz Klimsza) atp.

I další Františákovy texty pro karolinský soubor měly v realizaci rysy této „obousměrnosti“: hru Nevěsta uvedl jako režisér hned rok po premiéře v Karolince (2009) v ostravském Divadle Petra Bezruče (s představou tohoto dvojího uvedení hra již vznikala), inscenace kromě autorské režie spojovala i účast herce Josefa Králíka v karolinské inscenaci hrál roli Starosty, v Ostravě Starého Kučery. ${ }^{15}$ Naopak dramatizace Adventu Jarmily Glazarové, kterou Františák napsal pro Jihočeské divadlo České Budějovice (měla zde premiéru roku 2013 v autorově režii), byla uvedena i v Karolince (2015, režie Gustav Řezníček) a Františák na dramatizaci pracoval už s představou uvedení v Karolince (děj Adventu se ostatně odehrává jen několik kilometrů od Karolinky).

Levínský a Františák tak představují svými přesuny mezi divadlem profesionálním a amatérským zřejmě nejvýznamnější „hraniční jevy“ zkoumaného období. Mým záměrem však není zkoumání dotyčných hranic - naopak chci představit autory, jejichž tvorba doposud nedosáhla výraznějšího uznání mimo oblast amatérského divadla (knižní či časopisecké vydání, inscenování textů profesionálními divadly, soustavnější kritická reflexe mimo amatérská periodika atp.). Jde zároveň o tvůrce, jejichž tvorba výrazně vychází právě z tvưrčích a provozních specifik amatérského divadelnictví.

Výjimkami potvrzujícími pravidlo jsou v tomto ohledu u Lupince a Macháčka jednak dvojice profesionálních inscenací hry Kazimíra Lupince a Sonyi Štemberové Rozpaky zubaře Svatopluka Nováka (Divadlo ABC 2003, DAD Příbram 2014; je ovšem příznačné, že obě inscenace režíroval Milan Schejbal, tvůrce celoživotně s amatérským divadlem spjatý $\left.{ }^{16}\right)$, jednak libreto Petra Macháčka k opeře Petra Cíglera Táhlý zulněný pohyb podélného předmětu, jejíž uvedení v rámci Dnů nové opery Ostrava 2016 Macháček režíroval a podíleli se na něm i čtyři herci ,jeho“ Divadla Kámen. ${ }^{17}$

U Lupince i Macháčka můžeme hovořit o tvưrčí éře, kdy se jejich autorský rukopis rozvíjí ve spolupráci s konkrétním souborem, který uvádí jejich texty soustavně (v případě Macháčka pak výhradně). Kazimír Lupinec je bud’ spoluautorem, nebo výhradním autorem předlohy ke všem deseti inscenacím, které V.A.D. Kladno uvedlo od svého založení roku 1998 (jsou mezi nimi i dvě dramatizace, Vančurova Rozmarného léta a Klímova Utrpeni knižete Sternenhocha) v rámci své „hlavní tvorby“. Petr Macháček pak představuje v českém amatérském divadle zřejmě nejvýraznější příklad tvůrce rozvíjejícího určitou, velmi specifickou poetiku, záměrně ohledávajícího možnosti vyhraněného divadelního výrazu. Divadlo Kámen, které roku 1998 spoluzaložil, inscenuje od doby provedení Rakviček rakouské dramatičky Lotte Ingrischové (2003) výhradně Macháčkovy texty, a to s jedinou výjimkou v režii autora. ${ }^{18}$

15 Osobnosti Josefa Králíka je věnovaná speciální pozornost v rubrice Host v tomto čísle Theatralií.

16 Nejprve coby výrazný amatérský režisér pražského Anebdivadla 70. a 80. let, po absolutoriu DAMU a odchodu k profesionálnímu divadlu intenzivně aktivní lektor, porotce a pedagog četných seminářo̊ a workshopů.

17 Záznam inscenace je dostupný na webové adrese https://www.youtube.com/watch?v=dUH8JmpPGnw.

18 Tou výjimkou byla inscenace Výhled na řeku Labe (2013), kterou režíroval Martin J. Švejda. 
Oba autory tudíž spojuje spolupráce se souborem, který souzní s jejich autorskými záměry, svou existencí umožňuje jejich dramatickou tvorbu a zároveň ji podmiňuje svými specifiky. Macháčkova (od jeho tvưrčích počátků vyhraněná a dále se vyhraňující) poetika kladla vždy na herce nemalé a specifické nároky - svým zřetelným antipsychologismem na straně jedné a důrazem na artistnost práce s (významově vyprázdněnou) řečí na straně druhé. To vedlo jak (zejména v pánské části souboru) k značné personální fluktuaci v řadách Divadla Kámen (nebot' k běžné představě herecké [sebe]realizace má herectví Kamene dosti daleko), tak (zejména v dámské části souboru) ke stálému a zřetelnému vzestupu suverenity a artistnosti ve zvládání náročných autorských zadání. Tento vzestup byl logickým předpokladem dalšího experimentálního rozvíjení Macháčkovy poetiky.

Případ kladenského V.A.D. je opačný - generačně spřízněný kolektiv, jehož jádro zůstává po celou dobu existence souboru víceméně neměnné. Všechny inscenace V.A.D. jsou navíc kolektivně režírovány, což předpokládá výrazně sdílenou představu o divadle a společný smysl pro humor (vzhledem ke stylové jednotě, jakou tyto inscenace vykazují). Kazimír Lupinec je sice dominantním autorem souboru, ale všechny jeho texty jsou v průběhu inscenování do jisté míry kolektivně upravovány a dotvářeny.

Na tvorbu Petra Macháčka lze tedy (s jistým zjednodušením) poukázat jako na případ, kdy si autor snaží v maximální možné míře formovat soubor dle svých vyhraněných tvůrčích představ, a na práci Kazimíra Lupince jako na případ, kdy autor naopak do značné respektuje danosti dané specifiky souboru.

\section{Vztah autora a souboru - konkrétní příklad (Josef Tejkl)}

Pro zkoumání otázky soužití amatérského dramatika se svým souborem nám může jako specifický a v mnohém instruktivní příklad posloužit již zmíněný východočeský autor Josef Tejkl a „jeho soubory“ Černí šviháci a Samohana.

Josef Tejkl začal soustavně dramaticky tvořit v druhé polovině 80 . let pro královéhradecký soubor Obsazeno. ${ }^{19} \mathrm{~V}$ 90. letech uvádělo jeho texty prakticky výhradně královéhradecké Divadlo Jesličky, scéna ZUŠ/LŠU Na Střezině, kde Tejkl působil jako pedagog dramatické výchovy. Jesličky, soubor limitovaný personálně i provozně statutem „školní scény“, však uváděly především Tejklovy dramatizace ${ }^{20}$, nikoli jeho původní texty. ${ }^{21}$

Výrazný zlom v Tejklově tvorbě přichází roku 2002, kdy založil v Kostelci nad Orlicí soubor Černí šviháci. Do své smrti roku 2009 pro ně napsal a zrežíroval šest her²2, další

19 Napsal pro něj hry Cesta z hlíny do hliny, Pozor, chromý pes! a dramatizaci povídky Ivana Vyskočila Náš Berti, které se dle Otty Linharta (LINHART 2016: 14) nedochovaly.

20 Např. Balzacova Succuba, Čechovův Pavilón č. 6, koláž z Averčenkových povídek Beregov.

21 „Protože jsem v Jesličkách neměl kapacity typů, které by pro takové texty byly vhodné, psal jsem do šuplíku, nebo jsem s tím naivně obesílal soutěže." (HULEC 2003: 64)

22 Amatéri, Solný sloupy, Čilimnik, Bili andèlé piji tesavelu, Cechy krásné, cechy mé, Svět podle Kloboučka. Pro Černé šviháky napsal Tejkl i pohádkovou hříčku Jak čerti lechtali Rampušáka. Po Tejklově smrti uvedli Černí šviháci i jeho hru z 90. let Polyhistoři (2011, režie Radvan Pácl). 
dva autorské texty inscenoval se souborem Samohana. ${ }^{23}$ Vlivem spolupráce se zmíněnými soubory tak v jeho tvorbě došlo k boomu kvalitativnímu i kvantitativnímu.

V případě Černých Šviháků šlo o fenomén velmi obtížně popsatelný odborným jazykem, který vybízí k uchýlení se k problematickým termínům jako „autenticita“, „syrovost“ či „lidská originalita“. ${ }^{24}$ Faktem je, že divadelní zkušenost či řemeslná výbava nehrála pro Tejkla coby „principála“ při sestavování souboru evidentně klíčovou roli (podobně tomu ostatně bylo i v případě Obsazena ${ }^{25}$ ), důležitější byl specificky lidský půvab, postoj k životu či osobnostní téma. V poněkud feminizovaném prostředí amatérského divadla působili Černí Šviháci spíše jako pánský hospodský26 ${ }^{6}$ spolek poměrně razantního vystupování na jevišti i mimo něj, což ideálně korespondovalo s poněkud machistickým tónem Tejklových her, v nichž jsou ženy nezřídka drasticky karikovány. Rudimentární jevištní projev Šviháků byl v souladu i s jistou řemeslnou nedbalostí (nikoliv nepoučeností!) Tejklových režií. V tomto ohledu Tejklovy inscenace sdílely výhody i nevýhody amatérismu v takřka ryzí podobě, jak to výstižně postihl Jan Císař v bilančním nekrologu:

Pepík netoužil po divadelní dokonalosti, která by stála na jakýchkoliv a jakkoliv uznávaných konvencích a normách. Nemohl třeba přistoupit ani na běžné škrty, které by jeho text zkracovaly na obvyklou délku a zrychlovaly spád představení. Musel vést své dialogy v šíri, o níž byl přesvědčen, že sdělují všechno, co považoval za nutné. [...] Vyčítali jsme mu, že si jako režisér škodí, že by měl nechat své texty režírovat také někoho jiného, že neodstraňuje nedostatky, jež byly z hlediska divadelní praxe evidentní. Ale bylo to pro něho těžké. To, co si vymyslel a svou imaginací představil už jako scénický tvar v podobě textové, musel dokončit za každou cenu na jevišti, aby došel bez ohledu na cokoliv až na konec snažení uskutečnit svá předsevzetí. (CÍSǍ̌ 2009b: 77)

Volbu mezi osobitostí a řemeslnou perfekcí řešil Tejkl ve prospěch osobitosti, byl si však tohoto dilematu evidentně vědom, jak dokazuje založení vůči Švihákům odlišně koncipovaného souboru Samohana, s nímž vytvořil svou zřejmě nejlepší inscenaci, Asteroida Bejčka (v níž se opřel o zkušenou hereckou suverenitu Jana Bílka a Jany Portykové). ${ }^{27}$

Otto Linhart ve své práci Dramatika Josefa Tejkla (LINHART 2016), která představuje doposud jediný ucelenější pohled na Tejklovo dramatické dílo, nachází (s četnými

23 Jedná se o hry Asteroid Bejček a Země pokladů.

24 „V Jesličkách pěstuju [...] takovou uměřenější polohu, nazvěme jí klasičtější. Na texty typu Amatérů tam nemám ty správné živly. Ti jsou v Kostelci nad Orlicí, odkud pocházím a kde ted' bydlím. Tam je jistý undergroundový zdroj, který nevysychá a je tam neustále přítomen. Stačí se jen projít po hospodách a obsazovat.“ (HULEC 2003: 65)

25 „A aby toho neměl málo, založil podivné uskupení - divadelní soubor OBSAZENO, složený zčásti z hradeckých ochotníků, zčásti ze svých žáků, zčásti ze svých turisticko-horských kumpánů, zčásti ze svých milenek. Ochotníci s divadelními zkušenostmi v tomto souboru nepřevažovali. Na výsledku to sice bylo trochu vidět, ale zato to byla zajímavá společnost [...]." (DVOŘÁK 2002: 41)

26 Název souboru byl koneckonců odvozen od oblíbeného českého alkoholického nápoje zvaného fernet.

27 Za vrchol Tejklovy divadelní práce tuto inscenaci pokládá i Jan Císař ve zmíněném článku (CísǍ̌ 2009b). 
odkazy na Rotreklovu knihu Barokni fenomén v současnosti) zdroj jeho tvorby v baroku. Nejde jen o samotné (několikeré) zpracování historických látek z období baroka v Tejklově díle (nejvýznamněji v dramatickém životopisu sochaře Jiřího Františka Pacáka ve variantních hrách Kosou na kameni a Kalvárie): barokní „životní pocit“ utkvěl v jeho textech hlouběji.

Jde předeším o rozpětí tematické. Barokně vypjatá polarita bahna a hvězd, hospody a chrámu je v Tejklových textech setrvale přítomna a případné vychýlení tématu k jednomu pólu bývá kompenzováno zdůrazněním pólu druhého. Je-li tudíž hrdinou hry astronom (Asteroid Bejček), jsou jeho kosmologické meditace vyvažovány detailním líčením jeho partnerských obtíží; odehrává-li se hra v krčmě nejnižší cenové skupiny a jejím tématem je kupčení s mrtvými (Amatéri), je to záměrně kontrastováno vznosným slovníkem hlavního hrdiny (funebrák Mědílek), plným biblických aluzí a parafrází.

Zmíněné rozpětí se ale projevuje i v jazyce Tejklových her: je košatý, zdobný a ornamentální, plný archaicky znějících vazeb a méně obvyklých synonym (včetně scénických poznámek!). Vznosnost jazyka ovšem vůbec nevylučuje časté užívání vulgarismů, hovorových výrazů, rozličných žargonů a argotů. Tejklovi protagonisté jsou vesměs rétoricky zruční, libují si v dlouhých promluvách, pohotová výmluvnost bývá v dramatických střetech jejich klíčovou výhodou.

Rozsah jejich „řečí“ nemá tudíž leckdy adekvátní divadelní míru (viz výše citované Císařovo: „Musel vést své dialogy v šíři, o níž byl přesvědčen, že sdělují všechno, co považoval za nutné.“) - společně se skutečností, že jazyková a rétorická náročnost Tejklových textů byla v praxi leckdy nad síly režiséra Tejkla a jeho herců, ${ }^{28}$ by tento fakt mohl být paradoxně argumentem pro knižní vydání jeho her. Na základě porovnání své divácké a čtenářské zkušenosti se domnívám, že by mohly (a měly) dojít většího ohlasu spíše jako literatura.

Markantním příkladem literárnosti jeho textů je „abeceda venkovského kopáče“ Bili andělé piji tesavelu - kompozičně rozbíhavý text má základ ve vespolné „ožíračce“ kosteleckého fotbalového týmu v restauraci Panský dům, kde se probírá účast na blížícím se turnaji v Topol’čanech, a především se vypráví nekončící kaskády historek točící se kolem venkovského fotbalu. V nich se ovšem ukazuje Tejklova největší síla: cit pro vypravěčskou zkratku, ostré střídání různých stylových i jazykových rejstříků, hutnost a obraznost slovního vyjádření. Zároveň se zde ukazuje jako legitimní dědic hrabalovského hospodského „pábitelstvi““.

Zadroba: Pánové, největší pumelice má Jarda Sršeň ve Zdelově. Ten dyž kope z pětačtyřiceti metrů trestňák, tak de dobrovolně eště pět metrů dozadu, aby nepřestřelil. Tuhle mně dá břevno a vzteká se: „Kurva, eště metr dozadu, a neškrt by sis.“ (TEJKL 2006: 15)

28 Tento postřeh se kupř́ḱladu v Císařových textech o Tejklovi opakuje několikrát, tř̌eba v kritické zmínce o poslední Tejklově inscenaci, Zemi pokladi̊: „Režisér Tejkl bohužel nezvládl šanci, kterou mu dal autor Tejkl. Až na [...] Bohunu Jany Portykové ostatní postavy odř́kávaly nějak slova a jejich pohyb na jevišti byl neuspořádaný a neorganizovaný, takže málokdy mohla z této půdy vzkličit situace." (CÍSAǨ 2009c) 
Sláma: Tak to já si hned beru slovo, poněvadž Vorla sem proslavil já. Von to byl dřív takovej bezvýznamnej kopáč, ale jednou sem ho pozval na mejdan a vod tý doby je slavnej. Před mejdanem se menoval Křižan, po mejdanu Vorel. Před mejdanem nelétavý červ, po mejdanu král nebes!

Hoši, co sved Vorel, na to Copperfield nemá. Ve čtvrtým patře, tam sem bydlel, si vobul křápy. A jako že má dost a maže domů. Najednou se vyšvih na zábradlí, vyseknul parádní stojku...a převážil se do tý strašný černý třicetimetrový šachty.

Rána - a ticho. Tak deme s chlapama po schodech sebrat, co z Vorla zbylo. Hledáme kusy mozku, játra a tak - jenže Vorel seděl jak mimino v kočárku a sladce dřímal. Teda - von ten kočárek už byl srovnanej se zemí, péra v prdeli, ale Vorel neměl ani škrábnutí!

(TEJKL 2006: 25)

Už tak rozvolněný tvar si Tejkl ještě zkomplikoval zarámováním rovinou divadla na divadle - vystupuje zde jednak Režisér, zaskakující postupně řadu chybějících herců, jednak Autor, jehož přítomnosti se Režisér stále obává, ten však ve svém monologu, který uzavírá první půlku hry, inscenaci nadšeně pochválí.

Paralela mezi ochotnickým divadlem a venkovským fotbalem je evidentní: trenérovi se dává mančaft dohromady stejně složitě jako režisérovi obsazení, trable se zkompletováním sestavy do Topol'čan se zrcadlí v režisérově zoufalém a neustálém zaskakování chybějících herců. ${ }^{29}$ Obě aktivity (pro Tejkla příznačně) jsou zde pojaty jako zřetelně mužské, umožňující být „chlapům mezi sebou“: zjevný je tudíž i nepřítel, kterým jsou manželky, zakazující mužům posedle jejich zábavu. Ty jsou v Bilých andělech personifikovány v obludně groteskní Blaženě, jejíž zoufalý závěrečný monolog neúprosně charakterizuje místo žen v tomto světě: mohou sice muže utlačovat, jak chtějí, nic to nemění na faktu, že ti se na rozdíl od nich dokáží bavit sami.

Toto přímočaře machistické vyznění - abychom se vrátili k problematice vztahu dramatik-soubor - bylo v inscenaci Černých šviháků ovšem relativizováno tím, že roli Blaženy hrál také muž. Bez interního vhledu do situace lze jen stěží říci, do jaké míry nalezl Tejkl v Černých švihácích kolektiv souznící s tématy i formou jeho textu a do jaké míry naopak tento svérázný „pánský spolek“ podmiňoval jeho hry tvarově i tematicky: vzájemné ovlivňování zde bývá komplikované a víceúrovňové. Tak či tak bylo v konkrétní inscenaci výsledkem mimořádné souznění souboru s vypjatou groteskností textu, jeho surovým humorem a nezřídka brutální tematikou - ale také nesporné rezervy ve schopnosti herců zvládnout náročnou jazykovou stylizaci textu, stejně jako ve schopnosti režiséra učinit komplikovanou stavbu hry jevištně čitelnou. Tento rozpor je v něčem pro amatérské divadlo charakteristický a příznačný.

Vstupuje-li totiž profesionální dramatik (obzvláště s jistým renomé) se svým textem do prostoru, kde se pro realizaci tohoto textu nabízí relativně široká škála možností, pro amatérského dramatika je v naprosté většině případů existence „vlastního“ souboru conditio sine qua non jeho tvorby. Dává mu určitou jistotu realizace textů, umožňuje

29 Na základě dvojího zhlédnutí Tejklovy inscenace Bílých andělů s Černými šviháky si dovolím poznamenat, že tento koncept fungoval podstatně lépe v textu: už tak poněkud nepřehledný, stavebně rozvolněný tvar se přidáním této zcizující roviny inscenačně „zahustil“ až k nepřehlednosti. 
mu často i režijní „kontrolu“ nad touto realizací, zároveň však nevyhnutelně tento soubor svými limity jeho tvorbu v dobrém i zlém poznamenává.

Pokusím se nyní přejít od obecných úvah ke konkrétním zkoumáním a nabídnout avizovanou dvojici „př́ípadových studií“, věnovanou dvěma výrazným soudobým českým amatérským dramatikům a jejich souborům.

\section{Kazimír Lupinec - od parodie ke komediálnímu realismu}

Dramatickou prvotinu Kazimíra Lupince a inscenační prvotinu V.A.D. Sága rodu Rassini (1998) má smysl v autorově tvůrčím profilu registrovat především jako východisko: je to (pro začínající soubor příznačně) parodie, snad nejoblíbenější žánr studentského divadla. ${ }^{30}$ Téma je spolehlivě odlehlé - mafiánské filmy. Neparoduje se však žádná konkrétnější předloha, spíš jakási obecná sebevážnost klišovité představy o „mafiánské drsnosti“. Rámcový příběh (ženáč Pietro si začne s Elen Rassini, jejichž pět bratrů mafiánů klade na potenciálního muže jediné sestry vysoké nároky) spojuje několik scének, v nichž je okázale předváděná mafiánská drsnost vždy razantně shozena. Poněkud nedbale načrtnutý děj má však údernou pointu - otec Rassini, který se svým synům stále „zjevuje“ coby portrét nad rodinným stolem, v závěru odhalí, že když nemohl mít syna, ukradl postupně pět mimin a snažil se z nich tvrdým přístupem vychovat mafiány. Nepodařilo se a otec jim dává svolení, aby si každý zvolil povolání dle svých přirozených zálib.

Rozpaky zubaře Svatopluka Nováka (1999), které Lupinec napsal společně se Sonyou Štemberovou a které znamenaly svým ohlasem na JH 2001 první zásadní úspěch V.A.D., mají rovněž parodický základ, a to hned v několika rovinách: odkazuje se zde (názvem i strukturou) na populární seriál 80. let Rozpaky kuchaře Svatopluka ${ }^{31}$; ironizováno je lékařské prostředí, jedna z nejoblíbenějších kulis televizních seriálů; konečně inscenaci prostupuje jeden z nejbanálnějších postupů zejména studentského divadla - parodie TV reklam. Oproti Sáze se však Rozpaky vyznačují nepoměrně větší důsledností v rozvíjení a postupném „vytěžování“ vstupního nápadu. V žánru komediální jednoaktovky jde o vskutku dotažené dílo: nechybí tu gradace (nevinná sázka čtyř zubařů o to, kdo ošetří během měsíce nejvíc pacientů, roste touhou po výhře u všech do absurdní grotesky, kdy lékaři chodí shánět pacienty do ulic, přesvědčují k ošetření personál, v zběsilém finále hry si nakonec doktor Novák plombuje vlastní zdravé zuby), zřetelné typové rozvržení postav (plachý slušňák Novák versus razantní Kokeš, koketa Imrmanová versus podivínka Plicková) i překvapivý zvrat v závěru (primář Hofman, před kterým lékaři

30 „Není náhodou, že tolik autorů parodiemi začínalo [...], ale nikdo z nich u ní nevydržel až do zralého věku. Parodie je klasický studentský žánr: je to první, naivní reakce na tzv. vzdělání.“ (RUT 1995: 79)

31 Scénář František Filip a Jaroslav Dietl, režie František Filip, Československá televize 1984. Rozpaky kuchaře Svatopluka používaly (vzhledem k dobovým poměrům nepřiznaně) princip odvozený z legendárního Kinoautomatu, kdy diváci ovlivňují průběh děje svým hlasováním. Podobně jako v televizních Rozpacích, i v Lupincově a Štemberové hře je možnost diváků skutečně ovlivnit děj dosti relativní (po několika replikách se zápletka vždy „vrátí do stejných koleji“), diváci spíše rozhodují o tom, nakolik se má „slušný“ Novák kvůli vítězství morálně ponížit. 
celou dobu sázku tajili, o ní nejen celou dobu věděl, ale používal své lékaře jako tým v zápase „na vyšší úrovni“ s primářem sousední nemocnice). Ke komediální vitalitě tohoto jednoduchého, ale účinného dílka přispívá i vděčné prostředí zubařské ordinace (s málokterým dějištěm se pojí automaticky tolik diváckých emocî̉ ${ }^{2}$ ) a několikastupňové zapojování publika (kromě hlasování o dalším průběhu děje jsou dobrovolníci z publika „používáni“ i v rolích pacientů).

V pásmu „horrorů všedního dne“ Hotel Infercontinental (2000) parodických výstavbových principů ubývá, i když i nadále se zde důsledně pracuje s (pop)kulturními archetypy. Hlavní divácké potěšení zde spočívá ve stopování postupných narážek, které zdánlivě všední situace spojují s obecnými horrorovými topoi. To platí hlavně pro tři úvodní krátké scénky, které tvoří jakési „předtaktí“ titulní aktovky: postupně tak v prazvláštně se chovajícím milenci, který se u romantické večeře úporně dožaduje ryby, rozpoznáme vodníka; v sociální pracovnici, kontrolující nedbalou matku, polednici; a v realitním agentovi, který se snaží přesvědčit bodrý manželský pár, aby na pozemku v zahrádkářské kolonii postavil chatku jinde, upíra, pečujícího o „úložiště“ dalších upírů.

Přes hromadění narážek se situace ovšem záměrně nikdy zcela nepojmenuje - v „upírské“ scénce si dává Realitní agent se Zahrádkářem a Manželkou schůzku před svítáním, nebở ,je takhle zvyklý“ (LUPINEC 2002: 5), ponouká je k přesazení česneku do jiné části zahrádky, je nervózní z blížícího se svítání, poleká se křížku, který Manželka na pozemku vytrousí... Situaci ještě dotvoří, když Manželka okřikne Zahrádkáře „Ty mi teda piješ krev!“ (LUPINEC 2002: 7). Konec je však záměrně dvojznačný:

MANŽELKA: Rudolfe?! Vidís na to dobře?

ZAHRÁDKÁŘ: Prosimtě. (Tluče) Za deset, patnáct let se tady vocad’ nebudeš chtít ani hnout.

MANŽELKA: Počkej! Rudolfe! Vyndej to! (ZAHRÁDKÁŘ vytáhne kưl) Fuj! To je krev! (MAN$\check{Z} E L K A$ utiká pryč) Tady už nebudu ani minutu!

ZAHRÁDKÁŘ: (Prohlǐzi si zkrvavený kưl) Počkej! (jde za nì) To jsem asi trefil krtka... (LUPINEC 2002: 7)

Ani v titulní aktovce, rozsahem tvořící většinu hry, kde je dějiště zřejmé už názvem, slovo „peklo“ ani jednou nepadne. Má také nejblíže ke komediální moralitě - manželé Milerovi se přes množství zjevných varování v Hotelu Infercontinental nakonec ubytují, nebot nabízí „luxus za výhodnou cenu“, i o tu vařící vodu v hotelovém bazénu si nakonec řeknou sami, nebot se jim zprvu zdá být moc studená... Vladimír Zajíc dobře postřehl (ZAJÍC 2004: III), že podstatným tématem Infercontinentalu je napětí mezi užvaněností lidí a málomluvností bytostí, jakož i hlučné sebevědomí, s jakým se lidé vůči neznámému a numinóznímu chovají.

Za vrchol této „první fáze“ tvorby Lupince a V.A.D. považuji Tajemný VAD v Karpatech, zejména pro jeho nebývalou kompoziční rafinovanost. Vyrovnávat se parodicky s Verneovým Tajemným hradem v Karpatech po mimořádném filmovém Tajemstvi hradu

32 S výjimkou Feydeauovy aktovky „Kašlu na to!“, řekla Hortensie (Hortense a dit : „Je m'en fous!“, 1916) je přitom v komediální dramatice prakticky nevytěžené. 
v Karpatech (1981) Jiřího Brdečky a Oldřicha Lipského, to je na první pohled úkol téměř sebevražedný. Na rozdíl od Lipského filmu však ve hře Tajemný VAD není parodičnost tím dominantním, respektive se jaksi rozumí sama sebou. Verneův příběh je zhutněn do sedmi výjevů, které v zájmu scénické úspornosti uvede hlas autora, který dekoraci výjevu patřičně vyličí - skládá se tím i hold Verneově ornamentální popisnosti. ${ }^{33}$ Výjevy samy jsou pak koncipovány v naivním duchu jarmarečního divadla, s ostře konturovanými postavami. Určujícím prostředkem je zde verš - a to snad ten nejbanálnější český verš vůbec, který „bude současnému čtenáři pravděpodobně [...] konotovat nízkost, lidovost, písňovost, jednoduchost“ (IBRAHIM 2009: 373): osmislabičný trochej. Jeho přiznaně říkankový charakter je zdrojem parodizující naivity sám o sobě.

\section{RYCHTÁ̌̌: Tu je třeba důkaz dáti - rozvaliny prozkoumati}

DOKTOR: Jíti na hrad? Odsud? Zdola?

Co bude Verst bez doktora?

Nadmutí a neštovice

tasemnice, paznehtice

motolice, kurděje

než se někdo naděje.

(LUPINEC 2006: 2)

Zdrojem komediálního účinku je zde, v ověřené kabaretně-cimrmanovské tradici, rým: vynalézavý („Hřebenovky, traverzy/ mám již k horám averzi“, s. 10), groteskně nepatřičný („Při vzpomínce na Gorce/ vždy mu škube v pohorce“, s. 8), nabádavě nedopovězený (MIRIOTA: Já ubohá Miriota/ vzala jsem si... [MIRIOTA se rozpláče a odbihá za tatínkem], s. 3) i poněkud středoškolsky laciný („Niku Deku, ty vole!/ Podoben jsi mrtvole“, s. 5).

To podstatnější se však odehrává v paralelním dějovém pásmu, která se s verneovským příběhem pravidelně střídá - to vypráví příběh souboru V.A.D. (v němž herci vystupují pod svými jmény ${ }^{34}$ ), který se vydal do Karpat na studijní cestu k chystané inscenaci Tajemného hradu v Karpatech. Metakomentář této dějové vrstvy se rozvíjí ve dvou rovinách: v první guru souboru Lupinec postupně přichází na to, že celý výlet a řeči na něm vedené by mohly být součástí inscenace.

33 „JULIUS VERNE: V tom světle zpozoroval hrabě, že se dívá do staré hradní kaple. Jaká žalostná zpustlost zírala zde z každého kouta. Vzadu za oltářem čněl ještě do výše poslední zbytek krytby a posléze na hřebenu portálu chatrná zvonice, z níž visel až k zemi provaz onoho zvonu, který klinkával k nevýslovnému zděšení občanů verstských." (LUPINEC 2006: 11)

34 Respektive pseudonymy - celý soubor V.A.D. používá poeticky rozkošatělé pseudonymy: Jasanka Kajmanová, Růžena Roentgenová, Agáta Beránkovičová, František Šlukovrbovec... 
ŘíHA: To furt není důvod do tý inscenace dávat nás, jak chodíme na horách.

LUPINEC: No a co kdybysme tu hru vymejšleli během toho výletu jako ted'. To je dobrý - byly by tam ty naše rozhovory.

KAJMANOVÁ: Který?

LUPINEC: Tyhle.

KAJMANOVÁ: Jaký rozhovory?

LUPINEC: No tyhle, třeba i tenhle.

KAJMANOVÁ: Tenhle?

HUSMAROV: Tenhle rozhovor?

LUPINEC: No. Tak ten určitě ne. (LUPINEC 2006: 5)

V druhé pak události Tajemného hradu začnou do výletu souboru V.A.D. stále znepokojivěji vstupovat, aby se v závěrečném balábile promísily ve velké honičce Verneovy postavy s kladenskými herci. Tajemný VAD v Karpatech představuje svou stavebnou vynalézavostí, v níž se vstupní parodický impuls důmyslně komplikuje a přetvarovává, zřejmě vrchol „prvního období " tvorby V.A.D. ${ }^{35}$

Krátká jednoaktovka (vlastně spíše rozvinutý skeč) Píseček (2012) svou rodičovskou tematikou demonstruje generační posun souboru - při vší jednoduchosti (nejde zde vlastně o víc než o konfrontaci několika vyhraněných rodičovských typů při setkání na dětském pískovišti) se zde názorně ukazuje především Lupincův pozorovatelský talent a schopnost poslouchat. ${ }^{36}$ Jeho dialogy nepůsobí literárně cizelovaným dojmem, jsou naopak značně hovorové a plné běžné konverzační vaty: a přesto dokáží trefně vystihnout postavu i prostředí.

Tuto schopnost Lupinec zúročil ve svém (po mém soudu) doposud nejzralejším díle, černé komedii Upokojenkyně (2015). ${ }^{37}$ Pro autora i soubor šlo o pozoruhodné rozšíření žánrových možností: doposud se V.A.D. s výjimkou Utrpeni hraběte Sternenhocha věnovalo divadlu (řečeno bez vší pejorativnosti) čistě zábavnému. Projekty, které se tomuto profilu vymykaly, pak realizovalo jako jakousi „přidruženou výrobu“38 (platí to třeba o znamenité inscenaci Charmsovy pašije $[2014]^{39}$, propojující dílo Daniila Charmse s paměṫmi jeho druhé ženy).

$35 \mathrm{~K}$ prolnutí rovin došlo i ve vypravěčském komentáři Julia Verna, nebot jej v inscenaci V.A.D. (pod pseudonymem Benedikt Císařský) namluvil muž požívající mezi amatérskými divadelníky zřejmě největší odborné autority - prof. Jan Císař. Když pak ve snové scéně, kdy Lupinec usne sám před stanem a zdá se mu, že již s dokončenou inscenací předstupuje před „porotu“ Jiráskova Hronova, promluvil Císař coby vypravěč náhle „sám za sebe“, dodalo to inscenaci další metarovinu. (Byt samozřejmě na rozdíl od jiných metarovin zřejmou pouze těm, kteří se orientují v milieu českého amatérského divadla.)

36 V textu představujícím V.A.D. v rubrice Comedy Mix časopisu Svět a divadlo (ŠOTKOVSKÝ 2016) jsem volil - pro jejich relativní ucelenost a samostatnost - právě ukázky z Písečku.

37 V přehledu tvorby Lupince a V.A.D. jsem záměrně nechal stranou jak dramatizace - osobitou verzi Vančurova Rozmarného léta (2004) i méně zdařilou adaptaci Klímova Utrpení knižete Sternenhocha (2007), tak jednu z vrcholných inscenací souboru, kabaretně laděnou koláž Fe-érie o Kladně (2011), která se svým montážním charakterem do jisté míry vymyká celku Lupincovy tvorby.

38 Na webových stránkách souboru je ostatně rozdělena do sekcí Hlavní tvorba a Související tvorba.

39 Byla uvedena pod hlavičkou Ruský kroužek při divadle V.A.D. 
I Upokojenkyně jsou dílo komediální, otevírající ovšem s dosti hořkým podtónem jedno z vytěsňovaných témat dneška: péči o nemocné a nemohoucí seniory, která je nad síly jejich rodin, a tudíž vede $\mathrm{k}$ jejich přesunu do různých (leckdy problematických) zdravotnických zařízení.

Sama zápletka je poměrně jednoduchá: stará paní Vrbičková, za níž dochází do podobného zařízení (pravidelně) její syn Vlastík a (méně pravidelně) její vnuk Jarda, má již značné potíže s pamětí i vnímáním reality. Odpoví tudíž (není záměrně zcela jasné, jak moc promyšleně) při jedné návštěvě Jardovi na dotaz, co by si přála k narozeninám, že by bylo nejlepší, kdyby ji zabili. Syn s vnukem po debatě dospějí k tomu, že by to pro babičku skutečně byla úleva. Vražedný pokus však nadvakrát selže: druhý vnuk, který žije v Austrálii a babičku již př́liš nezná (a kterého si právě proto k vykonání činu vyberou), omylem zadusí babiččinu spolubydlící. Při druhém pokusu pak otrávené tvarohové buchty (které babička miluje), sní mladá sestra, která bezmocné pacienty cíleně okrádá. Příběh skutečně uzavírá babiččina (přirozená) smrt, pojednaná ovšem snovým, diváka záměrně znejištujícím zpo̊sobem (jako bizarní svatba s ireálně, „prvorepublikově“ působícím „panem Oldřichem“, který zde reprezentuje roli laskavého anděla smrti).

Konverzační humor (značně černý) je zde dvojího typu. První vychází z mimoběžnosti dialogů Vlastíka s jeho matkou a její spolubydlící paní Ptáčkovou. Absurdita promluv s dvěma dámami, nacházejícími se mentálně vesměs mimo realitu, je zde vytěžena důsledně, až do bizarních situací, kdy Ptáčková prohlašuje Vlastíka za svého syna a paní Vrbičková ho kárá, že se ke své matce nehlásí. Při vší přirozené vtipnosti je však evidentní Vlastíkem pocitovaná úmornost podobných rozprav, vedených týden co týden. ${ }^{40}$

Anna: A ty víss, jak to máš udělat?

Vlastík: Mami, ty děláš, jako bych ti ho vařil prvně.

Anna: No, zas tolikrát jsi mi ho nedělal...

Vlastík: Prosím tě mami, chodím ti sem to kafe dělat dvanáct let, tak mě prosím tě nepoučuj.

Anna: Ty? Prosím tě! Ty jsi tady byl tak dvakrát nebo třikrát.

Vlastík: Mami, já jsem Vlastík. Ty si mě pleteš s bráchou, ten tady byl tak třikrát. No nedá se nic dělat, budeme muset opakovat. Takže, já jsem tvůj co?

Anna: (po krátké pauze) Otec.

(LUPINEC 2015:2)

Druhý typ dialogické komiky tvoří rozpravy Vlastíka s Jardou, potažmo Erikem, jejichž černý humor povstává z rozporu mezi reálností a neodvolatelností připravovaných (či provedených) vražd a bezelstností, s níž o nich dotyční „mudrují“.

Jarda: Tati! Nutil babi někdo jíst ty buchtičky? Nenutil.... Prostě Rosta támhle někde v laborce něco namíchal, pak se to nějak připletlo do tvarohovejch buchtiček, který jsme si náhodou

40 „Nuže, dámy a pánové, jsem ve věku, kdy bych se tímto představením mohl cítit dotčen - a necítím. Naopak si myslím, že postihuje své téma s osvobozujícím humorem, protože ono tu vůbec nejde o to stáří, ale o ty mladší, kteří se musí vyrovnávat s tím, že opatrují nemohoucností a chorobami postižené rodiče a prarodiče." (CÍSAǨ 2015) 
chvilku položili na noční stolek u babi. To je celý!

Vlastík: Hele, ty jsi štastnej člověk ty vole. Mít tak trochu tvýho optimismu! A Ptáčková?! Tam jsme si jí taky jen tak položili polštář na ksicht?

Jarda: Vždyè ta už na to taky čekala jako na smilování.

Vlastík: Nečekala! Čekala, jestli vnuk udělá diplomku.

Jarda: Jestli je to ten, co tam byl před tejdnem, tak ten žádnou diplomku nikdy neudělá, to ti můžu garantovat! A to by s ní pak stejně seklo, až by zjistila, že ho vyhodili.

(LUPINEC 2015: 15)

Při vší humornosti se tu v ničem nezastírá krutost, plynoucí jak ze samotného faktu nemohoucnosti starého člověka a jeho závislosti na péči okolí, ${ }^{41}$ tak z cynismu zdravotnického personálu. Jeho odpudivou podobu reprezentuje jednak arogantní sestra Marcela, záměrně okrádající bezmocné seniory (poetická spravedlnost ji pak za to „potrestá“ smrtí otrávenými buchtičkami), jednak pragmatický ředitel Šváb, jehož postupné avansování z místního údržbáře až k členovi obecního zastupitelstva tvoří nepřehlédnutelné vedlejší téma (scéna, v níž přichází s volební urnou za polospícími Vrbičkovou a Ptáčkovou, aby „jejich prostřednictvím“ zvolil sám sebe, je jedním z vrcholných gagů hry).

Z žánrového zařazení realistické černé komedie se text poněkud vymyká průběžným znejištováním, do jaké míry odpovídají tvrzení paní Vrbičkové a paní Ptáčkové realitě. ${ }^{42}$ V úvodní scéně totiž přistoupíme na konvenci, že staré dámy už skutečnost příliš nevnímají, když vidíme, že paní Vrbičková si nepamatuje, že Vlastík je její syn a naopak jej za svého syna označuje paní Ptáčková. Nejistota ovšem vznikne, když vzápětí mluví paní Vrbičková o konkrétním extempore, který opilý Vlastík provedl při poslední návštěvě v pečovatelském domě: divácká pochybnost zde vzniká z předchozích evidentních náznaků, že Vlastík má problémy s alkoholem. Podobně když po vraždě paní Ptáčkové přichází Vlastík s Erikem „zkontrolovat situaci“, pozná v něm paní Vrbičková vraha (ačkoli si neuvědomí, že jde o jejího vnuka), v čemž jí pochopitelně nikdo nevěří. Diváka to však vybízí jak k revizi dosavadního přesvědčení o nevěrohodnosti a pomatenosti jejich tvrzení, tak ke zpětnému zvažování jejich předchozích výroků... Lapidárněji řečeno k tázání, kdo je vlastně více mimo realitu.

Lupincův autorský vývoj (a vývoj celého V.A.D.) je vlastně ukázkovým příkladem „zrání komediografa“ - od raných, razantně parodických a do sebe jakoby zapouzdřených dílek se posouvá k většímu zájmu o společnost i okolí, v humoru přibývá trpčích podtónů. Bujarou vitalitu postupně střídá ironická skepse, stárnutí generačního souboru odráží i tematika her.

41 Hořkost celé situace zesiluje i vědomí šedesátiletého Vlastíka, že se obdobným způsobem možná budou muset brzy starat jeho synové o něj. Je to vyjádřeno ve zkratce trpkým vtipem, kdy si Vlastík v obavě z duševního chátrání připraví kontrolní matematickou otázku, kterou mu má syn Jarda položit ke kontrole jeho příčetnosti („a jakmile udělám chybu, nemilosrdně ránu do hlavy“) - a když mu ji Jarda cvičně položí, splete odpověd'.

42 Soubor doplnil text komentářem, kde se pokusil tato „místa nejistoty“ pojmenovat a vysvětlit ,jak je to doopravdy“, ten však z povahy věci musíme vnímat pouze jako jednu z možných interpretací, nikoli nutně nejvíce validní (LUPINEC 2015). 


\section{Petr Macháček - od vyprazdňování jazyka k hudbě řeči}

Petr Macháček a jeho „dvorní soubor“ Divadlo Kámen zaznamenali na Jiráskových Hronovech solidní ohlas již s Macháčkovou inscenací vlastního textu Karkulka (2003) a Rakvičkami (2004) rakouské autorky Lotte Ingrischové. Pro etablování Macháčka a Divadla Kámen v povědomí českého amatérského divadelnictví však byla klíčová následující trojice textů a inscenací: Mlejnek (2005), Marmeláda (2006) a Žáby (2007). V nich také došlo k jistému vymezení hranic vlastní poetiky: prakticky ve všech dalších Macháčkových hrách jde o ověřování a prohlubování postupů, které rozvinul v těchto textech.

Mlejnek je žánrově ryzí pastiš některých osvědčených motivů televizních kriminálek, který satiricky dotahuje archetyp „drsného detektiva, pohybujícího se na hraně zákona“ do absurdních poloh. Jan Pavel Mlejnek ${ }^{43}$ se totiž pohybuje nikoli na hraně, ale za hranou zákona. I když jeho stále zdůrazňované policejní kvality nikdy nevidíme v praxi, jeho loajální podřízení Karel a Eda, milující partnerka a nepochybující šéf jsou mu nicméně připraveni odpustit vše.

Zápletka je relativně prostá: policejní komisař Mlejnek naváže patologický milostný poměr s vášnivou a emocionálně nestabilní Luisou. Když mu pak hrozí, že mu přeroste přes hlavu (Mlejnek má dlouhodobý vztah), nezbude než milenku zabít. „Zametání stop“ je pak dotaženo ad absurdum - až k zastřelení Prokurátora, který Mlejnka usvědčil z Luisiny vraždy. Mlejnkovi však projde vše: i nový příslušník jeho týmu Ferdinand, který k jeho obvinění poskytne důkazy, se na závěr za Mlejnka postaví. Nad tělem mrtvého Prokurátora se tak odvíjí ironický happy end, v němž víra všech v Mlejnka zůstává neotřesena jakoukoliv skutečností. Macháček zde důsledně zesměšňuje mediální ideál okázale drsného chlapáctví, které je zcela zbaveno účelu a existuje jakoby „samo o sobě“.

Hru Mlejnek s dalšími Macháčkovými texty spojují především tři formální postupy: prvním jsou důsledné repetice a refrénovitost dialogů, které jsou v Mlejnkovi použity především jako komický prostředek.

KOMISAŘ: Není dobré vynášet soudy bez podrobného přezkoumání, pane prokurátore.

PROKURÁTOR: Důkazy jsou naprosto jasné, pane vrchní komisaři.

KOMISA ̌̌: (zuyšuje hlas) Doporučoval bych vám nevynášet soudy bez podrobného přezkoumání, pane prokurátore.

PROKURÁTOR: Důkazy jsou naprosto jasné, pane vrchní komisaři.

KOMISAŘ: (dále zvyšuje hlas) Nesnáším vynášení soudů bez podrobného přezkoumání, pane prokurátore. (smírněji) Mlejnka z toho případu přirozeně odvolám, dokud se všechno nevyjasní.

PROKURÁTOR: (odmítavě kroutí hlavou) Důkazy jsou naprosto jasné, pane vrchní komisaři. (MACHÁČEK 2004: 24)

43 Jméno hrdiny je průhlednou narážkou na Jean-Paula Moulina, hlavního hrdinu proslulého francouzského kriminálního seriálu Komisař Moulin (1976-2008). 
Druhým charakteristickým rysem je silně kontrastní střídání jazykových rejstříků jednotlivých postav. Příznaková hovorovost Karla a Edy stojí vedle korektního vyjadřování „slušňáka“ Ferdinanda; odosobněle formální tón prokurátora kontrastuje s „drsňáckým“ Mlejnkovým jazykem, představujícím jakousi pokleslou variantu úsečně obrazného vyjadřování Chandlerova Phila Marlowa. ${ }^{44}$ Obzvláště kontrast vysoce formalizovaného, úředně působícího vyjadřování s nejrůznějšími profesními žargony zůstane pro Macháčka typický: „tvrd’ácký“ policejní jazyk, který v Mlejnkovi s viditelnou zálibností paroduje („Eště neumí pořádně naládovat stř́íkačku, eště ani neviděl naše zbroušený včeličky, [...] a už mě bude chtít zakatrovat jako svýho prvního vlastnoručně drapnutýho drbana?" [MACHÁČEK 2004: 21]), dojde využití i v postavě Detektiva v následující Marmeládě.

Třetím podstatným rysem je pak parodická kýčovitost samotné zápletky - vstoupíli do statického světa Macháčkových her dějový moment, je bud' okázale banální, nebo podobně okázale kýčovitý, sentimentální, vypůjčený z nejrůznějších pokleslých literárních i filmových vzorců. Příběhovost jako by Macháček viděl pouze ve dvou možných podobách: přízemně všední nebo odvozeně přepjatou. Ta pokleslost má navíc i do jisté míry antikvovanou podobu - viz Rostislavův „mstitelský příběh“ z Marmelády, který jako by vypadl z Pytlákovy schovanky:

Př́liš pozdě se začala ze své beznadějné závislosti léčit v ústavu. Glóblovy kyseliny, jí, Marto, strávily vnitřnosti. Když má sestra jela autem položit květiny na maminčin hrob, vjela oběma kolama na marmeládovou skvrnu na silnici a roztř́śstila si lebku o bytelnou zed' Glóblových závodů, Marto. Marto, jsem sirotek. Zůstal jsem bez jediné živé duše. (MACHÁČEK 2006: 22)

Byla-li Macháčkova tvorba (dosti povrchně) přirovnávána k Havlově dramatice ${ }^{45}$ má tato paralela u Mlejnka přeci jen nejvyšší oprávnění. Mlejnek jako by byl Macháčkovou Zahradni slavností dílkem mladistvě drzým, vzniklým suverénně důsledným rozpracováním jediného nápadu, zesměšňující různé typy frází a klišé, s výrazným parodickým nádechem.

Ostatně některé zmíněné charakteristiky (repetitivnost a refrénovitost jako komický nástroj, parodické užívání jazykových frází a klišé a dějových schémat) lze bez zábran vztáhnout i k Havlovu (zejména ranému) dílu. I důkladnost scénických poznámek, prozrazující autorovu jednoznačnou představu o temporytmické konstrukci díla, jakož i důraz na hudebnost jazykové stránky, která často nabývá vrchu nad sdělovanými významy, tvoří mezi dramatiky spojnici.

Největší rozdíl se tak odehrává na úrovni jazykové - Havlovy postavy až na výjimky neužívají hovorový jazyk (ani v parodické imitaci), promlouvají v brilantně logicky vystavěných promluvách, svou situaci dokáží často úderně pojmenovat. Napětí se v Havlových

44 Přesněji řečeno Macháček paroduje exploataci, které se chandlerovskému jazyku dostalo v televizních kriminálkách „moulinovského“ typu.

45 Viz blogový př́íspěvek Petra Macháčka na toto téma (odmítající tyto paralely) a následnou diskusi s Vladimírem Hulcem na iDN. Dostupné online na http://www.divadelni-noviny.cz/management-pritomnostipetra-oda-no-7. 
textech odehrává mezi suverenitou, s jakou protagonisté pojmenovávají svou situaci, a neochotou či neschopností ji aktivně řešit či měnit. Macháčkovy postavy se naopak vyjadřují vesměs mnohem prostším, repetitivnějším, frázovitým způsobem, často plným slovní vaty: své situaci, která je přesahuje nebo s kterou nejsou se schopni vyrovnat, už nejsou schopny čelit s havlovskou verbální brilantností, jsou vưči ní jakoby obnažené a bezmocné. V tomto ohledu představují Macháčkovy hry tvořivou odpověd' na někdejší úvahu Přemysla Ruta, že „originalita východního, satirického modelového dramatu je dalším dokladem, jak jsme si pro strach z úřadů nepustili k tělu úzkost z vesmíru. A ze sebe v něm“ (RUT 1993).

Jestliže absurdita Mlejnka je „žánrově kontrolovaná“ a svým způsobem hravá (Mlejnek popojiždí po městě s přilbou a v kožené bundě, ovšem místo očekávané motorky jezdí na koloběžce), pak Marmeláda je důslednou ionescovskou studií nehybnosti. Tato studie může ovšem zároveň působit jako satira na „českou“ pracovní pasivitu, provázenou neustálým rezignovaným očekáváním nejhoršího a stěžováním na poměry. (Viz příznačná mantra postavy Šéfa, rituálně se opakující povzdech: „Jo, dámy: kde na to všechno vzít, a nekrást.“) Pasivita je navíc nakažlivá - Kateřina s Martou, dvě „pilné včeličky“ společnosti Marmeláda International (MI), jsou sice nespokojeny s Šéfovou neochotou cokoli řešit, ale když přijde s iniciativou nový zaměstnanec Rostislav, okamžitě se mu rovněž snaží vysvětlit její nesmyslnost. Odvolávají se přitom na útlak, který na marmeládovém trhu provozuje magnát Glóbl, majitel firmy Marmeláda Global: příznačně se nikdy nedozvíme, nakolik je reálný a nakolik jde o fantóma, ospravedlňujícího pasivitu zaměstnanců MI. Do tohoto nehybného světa může děj vstoupit jen v parodické podobě - zde romantický, sociálně sentimentální příběh Rostislavovy pomsty na magnátu Glóblovi (viz výše citovaný monolog).

Absurdita je v Marmeládě všudypřítomná - dokazuje to i přítomnost slečny Agáty, zvláštní, nic nevědoucí a všemu se divící bytosti, které dá Šéf na konkursu na svou asistentku nepochopitelně přednost před mnohem kvalifikovanější adeptkou; s dějem nijak nesouvisející monology Detektiva, který přichází do MI bez jakéhokoliv důvodu vyprávět příběhy ze své policejní praxe; a konečně i závěrečné zjevení Glóbla, který vstupuje v plavkách a bílé košili, s velkými lyžařskými botami na nohou a doutníkem v ústech a celý svůj výstup se jen bez jediného slova směje (i když pojídá otrávenou marmeládu).

Parodičnost Mlejnka i extenzivní absurdita Marmelády se pak v Žábách vytrácí. Žáby jsou snad nejdůsledněji minimalistickou Macháčkovou hrou, lyrickým portrétem jediné zastavené situace. „Shrnutí děje“ (pokud připustíme, že v daném případě má tento pojem smysl) by znělo u Žab asi takto: Markétě a Antonínovi se ve sklepě přemnožily žáby, přichází za nimi jejich kamarádka Zuzana a o této situaci s nimi rozpráví. Vystřídají se u nich dva konzultanti, kteří jim radí, co s žábami provést. Nakonec Antonín vynosí žáby do lesní tůně.

Macháček zde zašel zřejmě nejdál v jakési „intenzifikaci banality“ - téma přemnožení žab, které působí fantaskně a groteskně zároveň, je podáváno s neotřesitelnou vážností, hodnou vypjatého psychologického dramatu. 

Z: Antonín je vyžene do zahrady?
E: (lehce znejistěla) Pokusí se o to. Pomocí vědra.
Z: Nebude to na ně přiliš tvrdé?
E: Antonín bude opatrný.
Z: Ano, ale, zahrada je dnes suchá a horká.
E: (znejistěla) Na to jsem nepomyslela, Zuzano.
E: Možná se mu to nepodaří.
E: Možná mu nenaskákají do vědra.
Z: Poměrně pálí slunce.

Přichází M. Pokládá prázdné vědro pobliž sklepa a zastavuje se.

M: Nepodařilo se mi to.

(MACHÁČEK 2008: 1-2)

Tato vážnost může na diváka dle naladění působit jistým hypnotickým lyrismem, komediálností nepřípadnosti situace a jednání postav v ní - anebo jej také prostě nudit svou repetitivností a monotónností.

$\mathrm{S}$ jistou nadsázkou se dá říci, že následující již téměř desetiletí Macháček rozvíjí motivy a postupy, které se objevily v trojici zmíněných textů. ${ }^{46}$ Pokusme se tedy o jejich alespoň částečnou katalogizaci.

a) Bylo již zmíněno, že Macháčkovy postavy se vyjadřují často (ne vždy) mnohomluvně, opakují svá sdělení v rozměrných refrénech plných vycpávek, parazitních slov a jazykové vaty, jejich řeč je často obecná, přerývaná, nedokončená. Jako by jeho postavy nevěřily, že jejich slova mají vůbec nějakou váhu, že vůbec dokáží něco změnit na skutečnosti, která je obklopuje.

Asi nejdůsledněji dokázal tuto „vatovost“ jazyka svých postav Macháček tematizovat v hříčce Ras al Chajma - kde prostinký dialog Matky s Dcerou, které řeší Dceřinu ztrátu mobilu a jeho případné zablokování, je „dublován“ postavou Vypravěče, která sám o sobě banální dialog sdělí ještě dříve, než jej pronesou postavy, a to s mnoha postradatelnými doplňky a redundantními sděleními. ${ }^{47}$

X: No a dcéra to jako vyřizuje, tu blokaci, né, blokaci normálně telefónu. Jako že volá tomu operátorovi, né. A řiká, ale zatím jenom matce to řiká, protože v telefónu nikoho neslyší, žejo, slyší tam jenom ty strojky, né, který jí ř́ikaj, že má zmáčknout jedničku pro českej jazyk né, a dvojku pro anglickej, né, a takový tyhle pokyny tam slyší, v tom telefónu, žejo, takhle toho hodně slyší a řiká. Řiká, jo, představte si, né, jak to řiká, né: Jo tyjo, tam jsou ty automaty šílený tady, tý jo, já nevim, jak se přes to dostanu, přes tohlecto, týjo to snad ani neni mož-

46 Na dlouho se takřka vytratila přímočará parodičnost Mlejnka, aby se po letech vrátila v nezávazně hravé Ztrátě obsahu v konfekčním obalu (2016) - tam kde Mlejnek „vyprazdňoval“ detektivní žánr, dekonstruuje Ztráta obvyklé postupy bulvárního divadla.

47 „[...] text sestává z vět plných opakování plevelných slovíček, z té nicnesdělující slovní hmoty, kterou spolu běžně hovoříme." (ZEMANČíKOVÁ 2012) 
ný, já nevim, co mám mačkat, mami. Přesně takhle to řiká svý mámě, jo: Jo tyjo, tam jsou ty automaty šílený tady, tý jo, já nevim, jak se přes to dostanu, přes tohlecto, týjo to snad ani neni možný, já nevim, co mám mačkat, mami.

(MACHÁČEK 2012b: 1)

Tento jazyk v Macháčkových hrách často kontrastuje s vysoce formalizovaným, složitým jazykem, kterým se vyjadřují úřady různého typu. Můžeme také často pozorovat bezradnost postav, když mají opustit tento „úřední jazyk“ a vyjádřit se „samy za sebe“. Když si pak Detektiv v Dopise poslaném poštou (2015) nasazuje gorilí masku a na otázky odpovídá pouze zvířecím řevem, jeví se to jako logická fáze vyprázdněné komunikace, kterou Macháček zobrazuje.

b) Jan Císař poznamenal trefně o Macháčkově minimalismu, že „abstrahuje životní stereotypy a konvence a krůček za krůčkem buduje jejich scénický obraz jako výraz opakující se únavnosti sociálního bytí“ (CÍSǍ̌ 2009a: 22). S jazykovou problematikou to úzce souvisí - unavený, vyprázdněný jazyk jen zrcadlí obdobnou unavenost postav. Macháček dává - a to je zřejmě jeho nejobecnější téma - ve svých hrách výraz světu bez lidské vůle.

Bohunce ve hře Zvěstováni Bohunce (2009) se dostane celkem trojího „navštívení: „je jí nabídnut naprosto nový model mobilního telefonu, kameník jí ohlásí, že udělal ,pěknej kámen‘, jenž jí věnuje a dá do bytu, a konečně Anděla, ,bílá a dost dokonalá jí zvěstuje, že se jí za dvanáct měsíců narodí dcera a Bohunka se má rozhodnout, jak se bude jmenovat" (ZEMANČÍKOVÁ 2012). Nejde zde jen o hodnotovou pokleslost, kdy Andělino zvěstování, které má zřejmé (byt do důsledku nepojmenované) náboženské konotace, je postaveno na stejnou rovinu jako nabídka telefonu: jde především o Bohunčinu bezmoc tváří v tvář situacím, které od ní vyžadují aktivní postoj.

Yvonně ve hře Deus ex offo je na začátku oznámeno, že je obviněna „z úkladné úmyslné krádeže schránky se šedými a modrozelenými diamanty za bílého slunečného dne za večerního šera z široce odemčeného historického archivu okresního muzea v malém nevýrazném okresním městě číslo třináct“ (MACHÁČEK 2012a: 2). Samotné oznámení obvinění už jako by znamenalo odsouzení - jak lapidárně konstatuje Obhájce: „Prostě jste jednou byla vobviněná, takže budete taky usvědčená, a potom samozřejmě taky vodsouzená, a my s tím tady nic nenaděláme, duša moja." (MACHÁČEK 2012a: 5) Yvonnina kamarádka Edita se nabídne, že za Yvonnu půjde do vyšetřovací vazby, aby se Yvonna mohla připravit na obhajobu. Yvonna ovšem nakonec ze strachu z vězení (,Jsou tam votřesný podmínky“, zní mnohokrát opakovaný refrén hry) si odmítne s Editou zpětně „vyměnit místo“ a Edita odchází místo Yvonny na dvaadvacet let do vězení. Ani jedna z nich ovšem nevyvíjí zřetelnou aktivitu, obě se trpně podřizují svému osudu, který vnímají jako nezměnitelný.

V tomto shrnutí by se Deus ex offo mohl jevit jako kafkovská variace na téma „viníka bez zločinu“, jen s lehce posunutými akcenty - proti Josefu K. je veden proces, aniž by se dozvěděl, z čeho je obviněn; zde je zločin konkrétní, ale kdo za něj bude potrestán, je v zásadě lhostejné. Zatímco Josef K. ale stojí proti majestátnímu a sebevědomému 
řádu, zde se reprezentanti řádu jeví v zásadě stejně bezmocní jako jeho oběti - Detektiv, který Yvonnu obviní, navštíví posléze téhož Psychiatra jako ona a není schopen prakticky dokončit větu, když se ptá, zda Yvonna podle Psychiatra zločin skutečně spáchala. A Psychiatr, k němuž se všichni obrací jako k nenáboženské variantě kněze, Detektivovi odpovídá takto:

P: Ty nejseš normální! Ty vole ty vubec nejseš normální! Dyk ty jseš uplně nenormální! Dojdi si na vyšetření, ty vole! Dyk ty jseš uplně mimo, ty vole! Dyk ty jseš uplně normálně blbej, ty vole! Dojdi si k psychiatrovi!

(MACHÁČEK 2012a: 19)

Tímto způsobem Psychiatr postupně reaguje na Yvonnnu, Editu i Detektiva. Tento nezájem o druhého a jeho sdělení je rubem pasivity postav - kdo nevěří v účinnost svých slov, nemá důvod poslouchat „slova druhých“. Prorok v Dopise poslaném poštou svá anglicky pronášená „moudra“ nechá pro jistotu (byt hovoří v prostých, základních větách) překládat tlumočníkem - přesto o ně nikdo nejeví zájem.

c) Jako kontrast s banální všedností „sociálního bytí“, kterou Macháček důsledně tematizuje (ne náhodou je oblíbeným dějištěm jeho her indiferentní kancelář), se v nich zjevují iracionální, fantaskně působící momenty - rozmnožení žab v Žábách, trojice záhadných „navštívení“ v Zvěstováni Bohunce, pravidelné zjevování Gorily, které nenese žádný racionální význam, v téže hře. V Ras al Chajma se (zcela mimo hlavní zápletku) objevují improvizované monology muže, který průběžně manipuluje s žlutou bednou, aniž by jakkoli naznačil její obsah či funkci v př́iběhu.

Vyložit, vysvětlit její existenci lze jen jediným zpo̊sobem: jako věc, jež prezentuje, ukazuje, manifestuje, „vylévá“ svou hmotnou podstatu, definuje sama sebe svým prostým bytím. Bylo kdysi řečeno, že postmodernismus je ontologický, že se zmocňuje skutečnosti v její konkrétní podobě. Mám podezření, že Petr Macháček takto pojímá divadlo, že svo̊j scénický systém vytváří tím, že uvolňuje prostor pro tuto manifestaci reálných prvků, aniž by mezi nimi vytvářel strukturální vazby a souvislosti toho typu, na nějž jsme v divadle zvyklí. (CÍSǍ̌ 2012)

d) Čím více se v Macháčkových hrách prosazuje nedůvěra k jazyku jako komunikačnímu nástroji, tím více v nich stoupá úloha sdělování mimojazykovou cestou. Divadlo Kámen tak intenzivně spolupracuje s hudebníky, kteří dostávají v inscenacích často téměř sólový prostor ke kreacím v duchu soudobé vážné hudby. ${ }^{48}$ A i tam, kde hudebníci chybí, má mluvní stránka věci důraznou hudební kompozici, kde monotónnost „nepsychologicky“ pronášeného textu je kontrastně narušována plochami jeku či řevu. Ve Zvěstováni Bohunce je každá z 38 scén hry ukončena repetitivně, výrazně rytmickou pasáží, která má být doprovázena hudbou a výrazně se tím vyděluje z celku předešlé situace ${ }^{49}$ Důraz

48 Obdobnou funkci plnily v Dopise poslaném poštou recitace vložených básní - i ty byly používány spíše ve své hudebně-rytmizační funkci, nikoli s důrazem na významovou stránku.

49 Viz v různých variantách opakovaný Bohunčin refrén: „Jsem si to myslela... Proč by se zrovna mně měla 
na formální stránku řeči je tak logickým pandánem její významové vyprázdněnosti. Macháčkův vstup na operní pole (v roli libretisty a inscenátora opery Petra Cíglera Táhlý zvlněný pohyb podélného predmětu) se zdá být logickým důsledkem jeho tvůrčího usilování.

Na závěr studie o textech Petra Macháčka a Divadle Kámen nelze zapřít, že se jedná o divadlo kladoucí značné nároky na divákovu vstř́ícnost, trpělivost a ochotu dobrat se k zážitku „únavnosti bytí“ skrze únavnost díla samotného. V tomto ohledu je Kámen divadlem vědomě a záměrně výlučným, o němž svým způsobem platí bonmot Vladimíra Mikulky pronesený při jedné z hronovských diskusí, kdy Kámen charakterizoval jako divadlo, o němž se „lépe mluví, než se na něj dívá“.

\section{Závěr}

Při analytickém zkoumání textů amatérských dramatiků narážíme na obdobné problémy, které byly v 70. a 80. letech charakteristické pro analýzu scénářu a textových předloh tzv. studiových divadel: obtížně si lze odmyslet specifickou poetiku souborů, pro něž texty vznikaly, stejně jako specifika celého komunikačního okruhu amatérského divadla, do něhož vstupovaly jejich inscenace. Přítomná studie vznikla z přesvědčení, že texty zmíněné trojice autorů tato specifika přesahují a mohly by dojít důraznějšího docenění jako texty přenositelné do jiných souborů a kontextů, př́ípadně (zde myslím zejména na hry Tejklovy) jako samostatné literární dílo. V případě textů Kazimíra Lupince tomu zřejmě do jisté míry brání autoritativní stín „původních“, velmi úspěšných inscenací dramatikova mateřského souboru - v případě her Petra Macháčka pak jejich silně technicistní forma, kdy jde o velmi podrobné inscenační scénáře, které jako by neposkytovaly takřka žádný prostor pro svébytný režijní výklad (odlišný od Macháčkova).

$\mathrm{V}$ úvodu práce jsem naznačil jistou paradoxnost stavu, kdy je amatérskému divadlu nezřídka věnována důsledná a kvalitní odborná reflexe - a kdy zároveň nejsou jeho špičkové výkony automaticky přijímány a reflektovány rovnocenně se špičkovými výkony divadla profesionálního. Tento stav se ovšem v poslední době do jisté míry proměňuje: signifikantními událostmi zde může být třeba přizvání amatérské loutkářky Hany Voříškové s její inscenací Pohyblivé obrázky na prestižní festival Divadlo Plzeň (2013) nebo nominace již zmíněných Upokojenkyň na Cenu Marka Ravenhilla za rok 2015.

Oproti divadlu profesionálnímu je „u amatérư“ mnohem zřetelnější síla vazby mezi amatérským dramatikem a konkrétním souborem, která se v profesionálním měřítku vyskytuje jen výjimečně (z poslední doby snad jen v případě Davida Drábka a hradeckého Klicperova divadla). Obecně lze snad konstatovat, že nejsilnější amatérské inscenace posledních let vznikají z kontinuální činnosti souborů, které rozvíjejí a cizelují konkrétní, vyhraněnou poetiku. Amatérské prostředí pak při všech svých limitech přeje tomuto cílenému pěstování určitého stylu více než prostředí profesionálního divadla.

narodit... S někym si mě spletla... Proč bych zrovna já měla mít PQQ dvacet šestku... Třeba mě chtěla podfouknout... Kam bych zrovna já ten hroznej kámen dala? Proč zrovna já? |: Já jsem jen Bohunka! Bohunka z Prahy Vysočan... :|“ (MACHÁČEK 2009: 7) 
P.S. V době závěrečných korektur této studie mi Petr Macháček ústně sdělil, že hodlají postupně usilovat o profesionalizaci Divadla Kámen a od jara tohoto roku se považují za profesionály. V produkční rovině má tato „změna statutu“ logicky zatím spíše deklarační význam, jejím důsledkem však je rozhodnutí souboru nadále se neúčastnit amatérských soutěžních přehlídek. Pozvolné „rozostřování hranic“ mezi amatérským a profesionálním divadlem v ČR tedy nadále pokračuje: čas prokáže, jaký vliv bude na přijímání Kamene v jeho nové pozici „stigma“ někdejšího amatérského souboru.

\section{Bibliografie}

CÍSǍ̌, Jan. 2009a. Jeden celý a dvě poloviny dne v Písku [One Day and Two Halves in Písek]. Amatérská scéna 46 (2009): 3: 20-23.

CÍ́SǍ̌, Jan. 2009b. Pamět divadla XIII věnovaná Pepíku Tejklovi [Memory of XIII Theatre Dedicated to Pepík Tejkl]. Amatérská scéna 46 (2009): 2: 76-78.

CÍSA ̌̌, Jan. 2009c. Východočeský standard v Červeném Kostelci [East Bohemian Standard in Červený Kostelec]. Amatérská scéna 46 (2009): 2: 39-41.

CÍ́SA ̌́, Jan. 2012. Tohle je divadlo? No to snad ne [Is This Theatre? I hope not]. Zpravodaj Jiráskova Hronova 5 (8. 8. 2015): 8.

CÍSǍ̌, Jan. 2015. Humor jako postoj k životu i k divadlu [Humor as Life and Theatre Attitude]. Zpravodaj Jiráskova Hronova 3 (3. 8. 2015): 8.

DVOǨÁK, Honza. 2002. Jak je důležité míti Josefa aneb O padesátníku, který by zasloužil korunu [The Importance of Having Josef or The Story of a Fifty-Year-Old In Need]. Amatérská scéna 40 (2002): 3: 40-41.

FIALOVÁ, Alena (ed.). 2014. V souřadnicích mnohosti: česká literatura proní dekády jednadvacátého stoleti v souvislostech a interpretacich [Merged in Multiplicity: Czech Literature in 2000s - Contexts and Interpretations]. Praha: Academia, 2014.

HRDINOVÁ, Radmila. 2005. Mrtvý chlap sám v hoře zpívá [Dead Man Sings in Mountain Alone]. Zpravodaj Jiráskova Hronova 7 (11. 8. 2005): 8.

HRUŠKA, Petr, Lubomír MACHALA, Libor VODIČKA a Jiří ZIZLER (edd.). 2008. V souřadnicích volnosti: česká literatura devadesátých let dvacátého století v interpretacích [Set in Sovereignty: Czech Literature in 1990s - Interpretations]. Praha: Academia, 2008.

HULEC, Vladimír. 2003. Mám zprávy, že Bůh existuje aneb Život je řeka, která stále teče. Rozhovor s Josefem Tejklem [I Heard News That God Existed or Life Is an Ever-Floating River. Interview With Josef Tejkl]. In Jan Dvořák (ed.). Orghast 2004: Almanach př̌šti vlny divadla: Revue Exotického Divadla [Orghast 2004. Almanac of the Next Theatre Wave: Exotic Theatre Revue]. Praha: Pražská scéna, 2003: 64-67.

IBRAHIM, Robert. 2009. Český alexandrín jako náhrada řeckého a latinského hexametru a pentametru [Czech Alexandrine As a Substitute For Greek nad Latin Hexameter and Pentameter]. Česká literatura 57 (2009): 3: 372-386.

JUNGMANNOVÁ, Lenka. 2014. Př́běhy obyčejných šilenstvi: „nová vlna“ “ěské dramatiky po roce 1989 [Stories of Common Madness: The "New Wave" of Czech Drama After 1989]. Praha: Filip Tomáš - Akropolis, 2014. 
KERBR, Jan. 2013. Krajina s akvabelami a černým domem: pokus o vymezení české polistopadové dramatiky [The Landscape With Synchronized Swimmers and a Black House: an Attempt at Defining Czech Post-November Drama]. Praha: Pulchra, 2013.

LINHART, Otto. 2016. Dramatika Josefa Tejkla [Drama Works by Josef Tejkl]. Praha: DAMU. Bakalářská práce. (nepubl.).

LUPINEC, Kazimír (\& Co.). 2002. Hotel Infercontinental. Strojopis ve vlastnictví autora [Manuscript in ownership of the author].

LUPINEC, Kazimír, Julius VERNE a V.A.D. 2006. Tajemný VAD v Karpatech [Mysterious VAD in the Carpathian Mountains]. Strojopis ve vlastnictví autora [Manuscript in ownership of the author].

LUPINEC, Kazimír (\& Co.). 2015. Upokojenkyně [The Quieteness]. Strojopis ve vlastnictví autora [Manuscript in ownership of the author].

MACHÁČEK, Petr. 2004. Mlejnek [The Grinder]. Strojopis ve vlastnictví autora [Manuscript in ownership of the author].

MACHÁČEK, Petr. 2006. Marmeláda [The Marmelade]. Strojopis ve vlastnictví autora [Manuscript in ownership of the author].

MACHÁČEK, Petr. 2008. Žáby [The Frogs]. Strojopis ve vlastnictví autora [Manuscript in ownership of the author].

MACHÁČEK, Petr. 2009. Zvěstováni Bohunce [Annunciation to Bohunka]. Strojopis ve vlastnictví autora [Manuscript in ownership of the author].

MACHÁČEK, Petr. 2012a. Deus ex offo. Strojopis ve vlastnictví autora [Manuscript in ownership of the author].

MACHÁČEK, Petr. 2012b. Ras al chajma. Strojopis ve vlastnictví autora [Manuscript in ownership of the author].

MIKULOVÁ, Iva. 2017. Př́iběhy obyčejných šílenství [Stories of Common Madness]. Theatralia 20 (2017): 1: 159-161.

RUT, Přemysl. 1993. Řeč nad rakví [Speech Over the Coffin]. Literární noviny 4 (1993): 13: 10.

RUT, Přemysl. 1995. Ptáček (n)eseje zpívá vesele [Bird Does Not Sow, It Sings Happily]. Brno: Petrov, 1995.

ŠOTKOVSKÝ, Jan. 2016. V.A.D. Kladno. Svět a divadlo 27 (2016): 3: 144-146.

TEJKL, Josef. 2006. Bíli andělé piji tesavelu [White Angles Drink Tesavela]. Strojopis [Manuscript], 46 stran.

ZAJÍC, Vladimír. 2004. Dramaturgický pendant ke hře Rozpaky zubaře Hotel Infercontinental [Dramaturgical Postscript to the Embarassed Dentist Hotel Infercontinental]. Amatérská scéna 41 (2004): 4: I-III (příloha Divadelni hry prověrené jevištěm).

ZEMANČÍKOVÁ, Alena. 2012. Divadelní provoz jako svěrací kazajka a amatérská nezávislost [Theatre Management As a Straitjacket and the Independency of Non-professionals]. Denik Referendum [online], 4. 6. 2012 [citováno dne 26. 4. 2017]. Dostupné online na http:// denikreferendum.cz/clanek/13300-divadelni-provoz-jako-sveraci-kazajka-a-amaterskanezavislost . 


\section{MgA. Jan Šotkovský, Ph.D.}

Ateliér muzikálového herectví

Divadelní fakulta JAMU v Brně

sotkovsky@jamu.cz

MgA. Jan Šotkovský, Ph.D. (1982) vystudoval divadelní dramaturgii na JAMU (2005), kde též po završení doktorského studia získal titul PhD. (2012). Působí jako dramaturg BURANTEATRu a Městského divadla Brno, překládá z polštiny a angličtiny, publikuje v Theatraliích a Divadelní revue. Zabývá se aplikací naratologie na výstavbu divadelního díla a problematikou scénické interpretace dramatického textu. Od roku 2005 působí soustavně jako porotce a recenzent na vrcholných přehlídkách českého amatérského divadla.

Jan Šotkovský (1982) graduated from Theatre Dramaturgy at Janáček Academy of Performing Arts in 2005 and received his Ph.D. at the same institution in 2012. He works as dramaturg in BURANTEATR and Městské divadlo Brno, translates from Polish and English, and publishes papers, reviews and critiques in journals Theatralia and Divadelní revue. Šotkovský's fields of interest comprise exploration of drama from the perspective of narratology, and analysing the process of staging drama. Šotkovský has been regularly invited to sit in juries and publish in journals at the most renowned Czech festivals of non-professional theatre since 2005. 